\title{
GENE STRICKLAND STUART
}

\author{
$1930-1993$
}

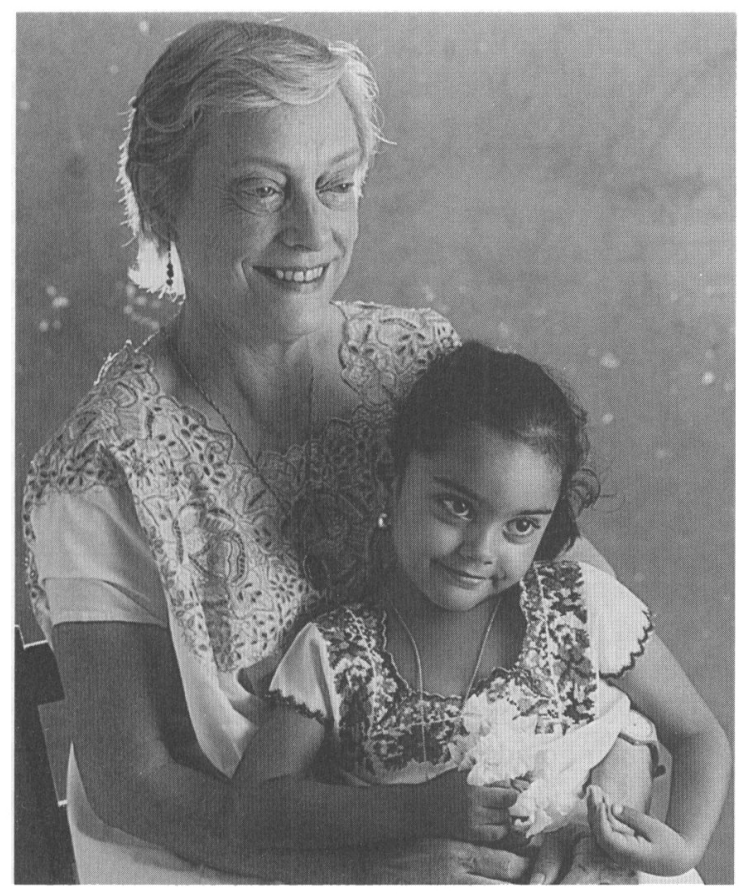

$\mathrm{W}$

hen Gene Strickland Stuart passed away in Silver Spring, Maryland, after a brave and difficult struggle with cancer on August 8, 1993, she left behind a legacy of good will, good works, and an extraordinary life that brought a large audience to studies of ancient America. With her husband, George Stuart, she was as responsible as any other for showing how vitally interesting Precolumbian cultures could be in attractive prose illustrated with evocative photographs and renderings. Through long association with Americanist archaeology, she possessed technical knowledge, but also that unusual "outsider's" view, capable of grasping what was important and intriguing to a broader public, yet in a manner that did justice to the material. Such intermediaries are a rare and precious thing, and Gene was one of the best. Her contributions, particularly to children's literature, were recognized formally with awards from the Educational Press Association of America (Distinguished Achievement Award for Picture Story, 1980), National Science Teachers Association (Outstanding Science Books for Children, 1980), and an award for children's literature from the government of Austria (1978).

Gene was born in Goldville (now Joanna), South Carolina, on October 22, 1930. Her advanced education began with a bachelor's in English and fine arts from the University of South Carolina. Later, she continued at the University of Georgia with courses toward a combined master's in art history and archaeology; her writing style developed further in 1970 and 1971, when she took courses in creative

American Antiquity, 60(4), 1995, pp. 685-687.

Copyright $\mathcal{C}$ by the Society for American Archaeology 
writing at the University of North Carolina, Chapel Hill. Gene's employment history was rich and varied, ranging from instruction in fine arts and art history at Anderson College, South Carolina, to archaeological assistant, artist, and laborer at Etowah Mounds, Georgia (1953-1954), Dzibilchaltun, Yucatán, Mexico (1958-1960), Balankanche (1959), and Cobá, Quintana Roo, Mexico (1974-1975). The first site formed a special interest of George Stuart, who began his archaeological career, with Gene's help, as a specialist in southeastern archaeology.

Dzibilchaltun and Cobá were in many respects the places that made the Stuarts one of the "first families" of Maya archaeology; at Cobá, Gene and George encouraged their son David's interest in Maya writing and art and cultivated his gift for hieroglyphic decipherment. Who can forget the photographs of George carrying David up a pyramid at Edzná, or of their other children sprinting near Precolumbian architecture elsewhere in Mesoamerica? The most exotic settings seemed within the grasp of young readers, and, to friends, Gene could always be relied on to advise on taking children to the field, how to deal with scabbed knees, stomach upsets, scorpion stings, and parental worries. The dustcover of George and Gene's last book, Lost Kingdoms of the Maya (1993), shows Gene, George, and David sharing a joke in the monumental splendor of Copán, Honduras, their last trip together to the Yucatán peninsula. They appear as I remember the family: happy, contented, at ease. At the National Geographic Society Gene held a variety of positions, among them staff writer for the Special Publications Division, managing editor of educational media, and, finally, as editor and senior writer with the Publications Division. In these positions, she traveled to Tonga, Prince Edward Island, and other locations, where she developed a solid and respectful rapport with indigenous peoples. Gene knew what she wanted, and had a clear sight on career fulfillment rather than professional advancement for its own sake. She much preferred to meet people and to establish new friendships; desk jobs held less fascination for her.

Perhaps Gene's most influential publication was The Mysterinus Maya, written with George, and one of the bestsellers of archaeological popularization (Stuart and Stuart 1977). It was for many of us a special book: a work of synthesis, it integrated ethnographic and archaeological information about the Maya in a compelling, highly readable fashion. Having spent time with modern Maya at Cobá and Dzibilchaltun - indeed, some of their grandchildren are part-Maya- - Gene and George discerned the filaments of cultural continuity in the Yucatán peninsula, and made an eloquent case for weaving such information together.

While preparing The Mysterious Maya, Gene encouraged another "weaver," Walter "Chip" Morris, one of the greatest living scholars of Maya textiles. Like Gene an outsider to the academic mainstream, Chip has become an active participant in the preservation, study, and revitalization of Maya textile weaving. Chip comments that Gene took him seriously when they first met in the mid-1970s, that they talked often of "prosecraft," for which Gene had a fine skill, and that she set him on a productive path in his study of native weaving in Quintana Roo, Mexico. Gene had remarked that Maya embroidery in Yucatán was often likened, enigmatically, to "stroking the snake." Only after intensive research did Chip find that much of the textile symbolism in Quintana Roo concerned snakes, their markings and parts-Gene's stray remark hit the bull's-eye. As a couple, she and George were well known for their help to younger scholars, who both appreciated and needed such assistance.

But what we remember best about Gene was her easy, gracious hospitality. Fellows at Dumbarton Oaks and other visitors to Washington, D.C., found good company in the Stuarts' comprehensive, subterranean library, surrounded by priceless first editions and memorabilia from Stuart travels. This is what we valued most about Gene: she was unpretentious, amiable and low key. She had a quick but never-cutting wit, paid kindly and thoughtful attention to other people, and had a clear notion of what she wanted to do and what would make herself and others happy. These qualities invest her books and, along with her diversely talented children, represent something we can still cherish. She is remembered fondly, and will be missed by all she touched. A memorial service at the National Geographic Society, held on August 23, 1993, in a large auditorium filled to capacity, showed in small part how many recollect her with affection. 
In recognition of Gene's life and works, an award established in her name is given by the Society for American Archaeology for outstanding examples of responsible archaeological reporting to the general public.

She leaves behind, besides her husband, four children: George, a Catholic priest; Roberto, a hotelier in Mérida, Yucatán; Ann, a veterinarian; and David, a top researcher in ancient Maya writing.

STEPHEN D. HOUSTON

Acknowledgments. The Stuart family generously shared their recollections of Gene, as did Chip Morris and John Monaghan. George Stuart provided a list of publications and filmstrips, a full list of which appears below.

\section{Bibliography of Gene S. Stuart}

1969 Discovering Man's Past in the Americas (with G. E. Stuart). National Geographic Society, Washington, D.C.

1972 Indians of North America. Special annotated supplement map to National Geographic 142(6).

1973 The Circle of My Family. In Writers by Moonlight: $I X$, edited by M. W. Wellman, pp. 24-29. University of North Carolina, Chapel Hill.

1974 History of the Indians of the Americas: A Conspectus. In Encyclopedia of Indians of the Americas, vol. 1, edited by K. Irvine, pp. 45-62. Scholarly Press, St. Claire Shores, Michigan.

Three Little Indians. National Geographic Society, Washington, D.C.

1977 The Mysterious Maya (with G. E. Stuart). National Geographic Society, Washington, D.C.

1979 Secrets from the Past. National Geographic Society, Washington, D.C.

Wildlife Alert! The Struggle to Survive. National Geographic Society, Washington, D.C.

1981 The Mighty Aztecs. National Geographic Society, Washington, D.C.

1982 Safari! National Geographic Society, Washington, D.C.

1983 A Blend of Sea and Shore: The Gulf Coast. In America's Hidden Corners, edited by P. D. Martin, pp. 116-143. National Geographic Society, Washington, D.C.

Cities that Show Their Age Proudly. In Preserving America's Past, edited by S. L. Fishbein, pp. 68-109. National Geographic Society, Washington, D.C.

The Pleasures of a Living Past. In Preserving America's Past, edited by S. L. Fishbein, pp. 6-31. National Geographic Society, Washington, D.C.

1984 Plateaus and Basins of the Southern Realms (Verde, Oaxaca, Querétaro, and the Middle Rio Grande). In Exploring America's Valleys: From the Shenandoah to the Rio Grande, edited by R. M. Crum, pp. 118-155. National Geographic Society, Washington, D.C.

1985 The Heart of Polynesia (Samoa). In Blue Horizons: Paradise Isles of the of the Pacific, edited by M. G. Dunn, pp. 10-35. National Geographic Society, Washington, D.C.
Polynesia's Last Kingdom (Tonga). In Blue Horizons: Paradise Isles of the of the Pacific, edited by M. G. Dunn, pp. 36-59. National Geographic Society, Washington, D.C.

South Sea Crossroads (Fiji). In Blue Horizons: Paradise Isles of the Pacific, edited by M. G. Dunn, pp. 60-87. National Geographic Society, Washington, D.C.

1986 Greece and Rome. In Builders of the Ancient World: Marvels of Engineering, edited by M. A. Harrell, pp. 38-69. National Geographic Society, Washington, D.C.

Whirlwinds and Thunderbolts. In Nature on the Rampage: Our Violent Earth, edited by M. G. Dunn, pp. 118-151. National Geographic Society, Washington, D.C.

1988 America's Ancient Cities. National Geography Society, Washington, D.C.

1991 The Historic Maritimes. In Canada's Incredible Coasts, edited by W. Gray, pp. 50-85. National Geographic Society, Washington, D.C.

1992 Mysteries of Mankind: Earth's Unexplained Landmarks (edited with M. B.Dickinson). National Geographic Society, Washington, D.C.

Palenque: Messages to the Gods. In Mysteries of Mankind: Earth's Unexplained Landmarks, edited by M. B. Dickinson and G. S. Stuart, pp. 26-47. National Geographic Society, Washington, D.C.

1993 Lost Kingdoms of the Maya (with G. E. Stuart). National Geographic Society, Washington, D.C.

\section{Filmstrips}

1973 Indians of North America (with G. E. Stuart). National Geographic Society, Washington, D.C.

1976 Indians of the Americas. National Geographic Society, Washington, D.C.

1977 The Life of American Indians. National Geographic Society, Washington, D.C.

1978 Mysteries of the Ancient World. National Geographic Society, Washington, D.C.

\section{Note}

1. The photograph of Gene and her granddaughter, Gloria Stuart Cach, was taken in 1988 by Rik Cooke. It appears courtesy of George Stuart. 


\section{NEW FROM CAMIBRIDGE}

\section{Olduval Gorge}

Vol. 5: Excavations in Beds III, IV and the Masek Beds

Mary Leakey, Editor

With Derk Roe

Olduvai Gorge in northern Tanzania is famous as a result of excavations conducted there since 1951 under the direction of Mary Leakey and her husband, the late Louis Leakey. This book records the archaeological finds in the upper part of the Olduvai Gorge sequence, covering the period 1.2 to 0.4 million years ago, and includes artifacts and faunal remains excavated from sites in Beds III, IV and the Masek Beds.

Contributors: R. L. Hay, Mary Leakey, D. A. Roe, $P$. Callow, P. R. Jones, Celia $K$. Nyamweru

33403-9 Hardback $\$ 175.00$

\section{Law, Violence, and Community in Classical Athens David Cohen}

Using comparative anthropological and historical perspectives, this analysis of the legal regulation of violence in Athenian society challenges traditional accounts of the development of the legal process. It examines theories of social conflict and the rule of law as well as actual litigation. Key Themes in Ancient History

38167-3 Hardback \$54.95

38837-6 Paperback $\$ 18.95$

\section{The Archaeology of}

\section{Early Historic South Asia}

The Emergence of Cities and States

Raymond Allchin

Drawing on archaeological studies, texts, and inscriptions, this analysis explores the character of the early Indian cities that developed between C. B.C. 800 and A.D. 250. It pays particular attention to their art and architecture and analyzes the political ideas that shaped the state systems.

Contributors: G. Erdosy, R. A. E. Coningham, D. K. Chakrabarti, B. Allchin

37547-9 Hardback \$74.95

37695-5 Paperback $\$ 29.95$

\section{Celtic Chlefiom, Celtic State}

Bettina Arnold and

Blair Gibson, Editors

In this collection, archaeologists, historians, geographers and language specialists re-examine the structure and political development of Celtic states scattered across present-day Europe.

Contributors: Patrice Brun, Carole Crumley,

Franz Fischer, Bettina Arnold, Olivier Buchsenschutz Michael Dietler, John Collts, Colin Haselgrove, Peter Wells, Robert Dodgshon, Sean Dunham, D. Blatr Gtbson, Nerys Patterson

New Directions in Archaeology

46469-2 Hardback about $\$ 49.95$

\section{Egyptian Art}

\section{Eleni Vassilika}

With contributions by Janine Bourriau

This lavishly illustrated book brings together a selection of ancient Egyptian works of art of outstanding quality and interest, explaining their significance, style, material, and mode of manufacture within the framework of the life and religious beliefs of the royal and private owners for whom they were made. Fitzwilliam Museum Handbooks

47519-8 Hardback \$44.95

47518-X Paperback \$15.95

Now in paperback...
The Return of
Cultural Treasures
Second Edition
Jeanette Greenfield
Introduction by
Magnus Magnusson
"... a very valuable and important work.
IGreenfield] presents fully researched
discussions of scores of cases argued
over many years concerning national
requests for 'repatriation' and 'return'
of art and artifacts allegedly or mani-
festly illegally removed. The good index
allows the book to be consulted for
specific cases."
-American Journal of Archaeology
$47170-2$ Hardback about \$74.95
$47746-8$ Paperback about $\$ 27.95$

Now in paperback..

The Returm of Cultural Treasures

Second Edition

Jeanette Greenfield

Introduction by

Magnus Magnusson

[Greenfield] presents fully researched

discussions of scores of cases argued

over many years concerning national requests for 'repatriation' and 'return' of art and artifacts allegedly or manifestly illegally removed. The good index allows the book to be consulted for ecific cases.

47170-2 Hardback about $\$ 74.95$

47746-8 Paperback about $\$ 27.95$

Available in bookstores or from 